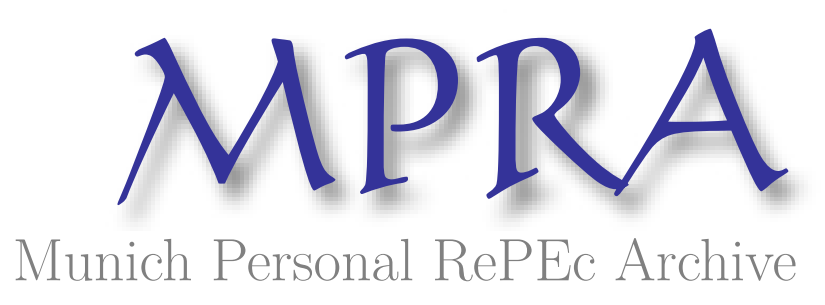

\title{
Public investment multipliers in EU countries: Does the efficiency of public sector matter?
}

Papaioannou, Sotiris

Centre of Planning and Economic Research

22 March 2016

Online at https://mpra.ub.uni-muenchen.de/70332/

MPRA Paper No. 70332, posted 29 Mar 2016 09:29 UTC 


\title{
Public investment multipliers in EU countries:
}

\section{Does the efficiency of public sector matter?}

\author{
Sotiris Papaioannou ${ }^{1}$ \\ Centre of Planning and Economic Research
}

\begin{abstract}
This study examines whether differences in public sector efficiency are associated with diverging effects of public investment on growth. At first stage, we estimate public investment multipliers for each country of the European Union (EU). Their size varies considerably across countries. Then we construct measures of public sector efficiency which are used in the econometric analysis to study the relationship between public investment and growth. The main result of the econometric analysis is that the efficiency of public sector indeed matters in raising the influence of public investment on growth. This result remains robust to several changes in the econometric specification and to various measures of government efficiency which used as explanatory variables in the econometric estimations.
\end{abstract}

Keywords: Public investments, Fiscal multipliers, Public sector efficiency, Economic growth.

JEL classification: E62, H30, O40.

\footnotetext{
${ }^{1}$ Sotiris Papaioannou, Address: 11 Amerikis Street, 10672 Athens, Greece, tel: +30-2103676426, email: $\underline{\text { sopa@kepe.gr. }}$
} 


\section{Introduction}

The role of fiscal policy and its effects on growth is one of the most extensively discussed issues in the modern macroeconomics' literature. The relevant theoretical literature predicts that fiscal policy can influence growth by supporting aggregate demand under a Keynesian manner, or can hamper growth through crowding out of the private sector, under neoclassical economic theory. Empirical studies find either that the public spending multiplier is greater than one or that it is well below unity. It seems that no consensus has yet emerged from empirically estimated models regarding the response of output to fiscal shocks, with the magnitude of the response depending on several country characteristics related to monetary policy, level of development and government debt.

Spending on public investments is a key component of fiscal policy as a means to stimulate economic growth and boost private investments. Figure 1 briefly illustrates the percentage of GDP that each European Union (EU) country spends on public investment. The question that arises is whether and to what extent does this kind of fiscal policy achieve its primary target? And if so, is its effect uniform across countries? This paper tries to answer this question by putting emphasis on the role of public sector efficiency in shaping the relation between public investments and economic growth.

At first stage we follow the approach of Balnchard and Perotti (2002) to set up a structural VAR econometric framework and estimate multipliers of public investment spending. Quarterly time series datasets are compiled for each EU country during the period 1995:Q1-2015:Q1. The obtained econometric results confirm that responses of output after a shock in government investment are not uniform across EU countries and vary significantly. The magnitude of the output response after a 
shock in public investment is positive for most of the EU countries however it remains very low or is even negative for fewer ones.

Then we follow the methodology of Afonso et al. (2005) to construct measures of public sector efficiency for EU-28 countries in the period 2004-2014. These measures compare the performance of public sector in several key areas such as administration, education, infrastructure and stabilization relative to the cost paid by the government, in the form of public expenditure, to achieve its policy objectives. We also construct a composite efficiency indicator comprising of individual efficiency measures and a technical efficiency indicator following the methodology of Battese and Coelli (1995).

These measures of public sector efficiency are incorporated into an econometric model to study the relationship between public investment and growth. The main result that arises from the econometric analysis is that the efficiency of public sector indeed matters in raising the influence of public investment on growth. This result remains robust to several changes in the econometric specification and to various measures of government efficiency that are used as explanatory variables in the econometric estimations. The main policy lesson to be learned from this study is that governments should focus more on the proper allocation of their resources as a means to maximize the growth influence of public investment.

The paper proceeds as follows: section 2 discusses the findings of the relevant literature. Section 3 presents public investment multipliers for each EU country. Section 4 constructs measures of public sector efficiency. Section 5 examines the influence of public sector efficiency on the public investment-growth relation. Finally, section 6 concludes. 


\section{Related literature}

This study is related to a large literature which examines the effects of fiscal policy on growth. Predictions of the theoretical literature are ambiguous as regards the influence of public spending on growth. General equilibrium new Keynesian models show that the government spending multiplier can be close or above one (Gali et al. 2007; Monacelli and Perotti 2008). On the other hand, standard real business cycle models are in sharp contrast to new Keynesian ones and deliver multipliers which are well below one (Baxter and King 1993; Burnside et al. 2004; Ramey 2011). The main reason for such a significant difference is that real business cycle models feature infinitely lived Ricardian households, whose consumption depends on an intertermporal budget constraint. Therefore any increase in government spending lowers the present value of income after taxes, generates negative wealth effects and leads to a decrease in consumption. ${ }^{2}$

Similarly, predictions of the empirical literature on the effects of fiscal policy on output are not uniform. Blanchard and Perotti (2002) show that shocks in government spending are associated with higher output of the US economy during the post war period, with the size of the multiplier being close to one. Monacelli et al. (2010) estimate a VAR model to evaluate the effects of U.S. government spending on

\footnotetext{
${ }^{2}$ Several studies have tried to reconcile predictions of neoclassical models with observed evidence which were in favor of a raise in consumption after an increase in government spending. Gali et al. (2007) extended a standard new Keynesian model to allow for the co-existence of infinite horizon Ricardian consumers and 'rule of thumb' consumers, which do not save and do not borrow. They showed that an interaction of rule of thumb consumers with sticky prices and deficit financing of government spending can account for higher consumption when spending increases. In a similar way, Hall (2009) developed a dynamic general equilibrium model which has as main features the decline in markups of prices over costs when output raises and the elastic response of employment when demand increases. With these features the model delivers quite high multipliers and increase in consumption. Recently, Cogan et al. (2010) showed that government spending multipliers are much smaller in new Keynesian models than old Keynesian ones, with the estimated stimulus in GDP being one sixth of what is predicted in old Keynesian ones.
} 
output and employment. Their results are in favor of a multiplier which is larger than one.

On the contrary, a part of the literature has identified non Keynesian effects of fiscal policy on output. Perotti (1999) evidenced several countries whose private consumption increased rather than contracted in periods of large fiscal consolidation and showed that in such periods the influence of fiscal policy is very different than in 'normal' times. Alesina and Ardagna (2010) showed that fiscal stimulus based on tax cuts is more likely to increase growth as compared to fiscal expansion based on spending increases. They also showed that adjustments based on spending cuts rather than tax increases are less likely to create recessions. In the same spirit Mountford and Uhlig (2009) showed that deficit financed government spending has weaker effects on output of the US economy as compared to deficit financed tax cuts.

It seems, however, that the effects of fiscal policy on private consumption and output have become weaker over time, with the influence being stronger in the pre 1980 period (Perotti 2005; 2007). Also, the response of output depends on country specific characteristics related to monetary policy (Christiano et al. 2011), exchange rate regime or trade openness (Ilzetzki et al. 2013) and level of government debt (Chung and Leeper 2007; Favero and Giavazzi 2007).

Building on the work of Afonso et al. (2005) who constructed public sector efficiency indicators, Angelopoulos et al. (2008) found evidence in favor of a non monotonic relation between government consumption and economic growth that depends critically on the level of public sector efficiency. Below a certain threshold level of public sector efficiency, the relation between public consumption and growth is negative whereas in most countries the influence of government consumption is negative. 


\section{Public investment multipliers}

A common approach to study the effects of fiscal policy on output is to use a standard VAR model. We start with estimating the following reduced form VAR:

$$
Z_{t}=A(L) Z_{t-1}+U_{t}
$$

where $Z_{t} \equiv\left(g c_{t}, g i_{t}, t_{t}, y_{t}, p_{t}, r_{t}\right)$ is the vector of endogenous variables. This specification includes quarterly data on the logs of government consumption $\left(g c_{t}\right)$, government investment $\left(g i_{t}\right)$, taxes net of government transfers $\left(t_{t}\right)$ and GDP $\left(y_{t}\right)$, with all four variables entering in real terms. It also includes a variable for the GDP deflator $\left(p_{t}\right)$, a variable for the 3-month money market rate $\left(r_{t}\right)$, as well as a deterministic constant term. All variables are seasonally adjusted except the GDP deflator and the interest rate. $A(L)$ is the autoregressive polynomial in the lag operator $\mathrm{L}$ and $U_{t} \equiv\left(u_{t}^{g c}, u_{t}^{g i} u_{t}^{t}, u_{t}^{y}, u_{t}^{p}, u_{t}^{r}\right)$ is the vector which contains the reduced form residuals.

A major drawback of the standard VAR specification is that if covariance between error disturbances is not zero, which is often the case, then the common component of error innovations is falsely attributed to the first variable entering the VAR. As a way to avoid this kind of bias, after estimating the reduced form model of equation (1), we proceed with the estimation of a structural VAR specification to identify exogenous fiscal policy shocks. These shocks are then used to derive impulse responses of output. More details on the construction of the structural VAR model are found in the Appendix.

For each EU-28 country we have compiled quarterly data from the National Accounts' database of Eurostat (2014), except for Croatia for which the data availability is very limited. The sample of the analysis covers the period from the first quarter of 1995 to the first quarter of 2015 , however the length of the time span for 
which data is available for all variables differs across countries. For each country, we have estimated a separate VAR system. The number of lags for each individual VAR was set so that no serial correlation existed in the residuals, the stability condition was satisfied and at least one of the information criteria was minimised.

After the estimation of the structural VAR's, a series of simulations was performed to trace the impact of shocks in public investment. The shocks were set equal to a positive one standard deviation and the impact of these shocks is illustrated with cumulative multipliers shown in Table 1 for various time horizons. We should note that the cumulative fiscal multiplier is defined as the ratio of the cumulative change in output, divided by the median interest rate, over the magnitude of the change in the public investment variable in period $t=1$ :

$$
\text { Public investment multiplier }=\frac{\sum_{t=1}^{n}\left(\Delta\left(y_{t}\right)^{*}(1+i)^{-1}\right)}{\Delta\left(G_{t=1}\right)} * \frac{1}{G / Y}
$$

where $y$ is output, $G$ is public investment and G/Y is the average GDP share of public investment.

For most of the EU countries, we observe that the sign of the multiplier of government investment is positive (Table 1), implying that an increase of government investment brings about a positive response of GDP. The highest response of output after a shock in public investments is observed in Germany, for which the multiplier reaches 2.08 four quarters after the initial shock. Highly positive multipliers are also observed for several other EU countries, suggesting that public investment spending is an effective tool for boosting the economy. Apart from short run influences on aggregate demand, supply side effects of public investment contribute to output growth, as a higher stock of public infrastructure results to higher marginal products of private inputs. 
We also encounter a number of countries for which the sign of their multiplier is low or even negative. Overall, the size of the multiplier for public investment varies significantly across countries entailing significant differences on the way the economies are affected by a shock in public investment. The existing empirical literature has proposed a number of reasons for which the effectiveness of fiscal policy differentiates from country to country. In this paper we will try to examine whether the economic outcome of fiscal policy depends on public sector characteristics related to government efficiency.

\section{Public sector efficiency}

We follow the spirit of Afonso et al. (2005) to construct sub-indices of public sector efficiency in selected key policy areas. The areas that we focus here are those of administration, infrastructure, education and stabilization. In addition, a total index of government efficiency is constructed as the average of the individual sub-indices. Based on data availability, we construct annual indices of government efficiency for all EU-28 countries during 2004-2014. The main insight of this indicator is to compare the performance of public sector in these policy areas, in relation to the expenditure required to achieve this performance. Therefore, for each key policy area we utilize measure or measures of public sector performance relative to measures of public spending.

In the policy area of administration, public sector performance is measured as the unweighted average of the variables of corruption perceptions index (available from Transparency International), protection of property rights (Economic Freedom of the World) and judicial independence (Economic Freedom of the World). The associated expenditure measure is that of the public consumption share in GDP, 
available from Penn World Tables 8.0 Database (see Feenstra et al 2013). In the area of stabilization, public sector performance is measured as the average of the inverse of the variables of unemployment and inflation (both available from World Development Indicators), while the share of public consumption in GDP is used as an expenditure measure. In the area of education, the public sector performance measure that we use is that of the tertiary school enrollment rate while the associated expenditure measure is public spending on education as a percentage of GDP (both variables are available from the World Development Indicators). ${ }^{3}$ Finally, in the area of infrastructure, we utilize the variables of the volume of freight carried by air transport, fixed telephone subscriptions per 100 people, internet users per 100 people and mobile cellular subscriptions per 100 people (all variables are available from World Development Indicators) to construct the public sector performance index. The share of public investment in GDP (available from Eurostat) is used as a measure of expenditure in this area.

In order to make the measures of public sector performance and public sector expenditure (expressed in different units of measurement) comparable across countries, we express each country's public sector performance and public sector expenditure measures relative to the average of all countries for each year. The resulting public sector efficiency index in each area emerges as the ratio of the relative public sector performance relative to the public sector expenditure measure. The total public sector performance index arises as the average of the sub-indices of public sector efficiency in the areas of administration, stabilization, education and infrastructure.

\footnotetext{
${ }^{3}$ For those years that we encountered missing values for public spending, we used the average value of this variable for the closest years.
} 
Table 2 reports selected public sector performance indicators for each of the four policy areas discussed previously as well as for the total public sector efficiency indicator. Countries are ordered according to the total index of public sector efficiency. As expected, high income EU countries get better than average scores. The most efficient public sectors in 2013 were those of Germany (2.26), Austria (1.92) and Ireland (1.76). In contrast, the least efficient ones in 2013 were those of Bulgaria (0.58), Slovakia (0.65) and Hungary (0.66).

These measures should be used with caution. For instance, in some countries like Estonia, Croatia, Portugal, Slovakia and Spain the efficiency index in the area of stabilization receives negative values mainly as the result of negative inflation in 2014. Also, in some countries for which the cost of providing public education is high (e.g. Sweden), or private resources complement government spending (e.g. Greece), we may be obtained with underestimated or overestimated, respectively, measures of government efficiency (see also Angelopoulos et al. 2008).

\section{Public investment, government efficiency and growth}

\subsection{Econometric model, data and variables}

The obtained multipliers, shown in Table 1, suggest that responses of output after a shock in public investment are not uniform across countries. A meaningful explanation for such variation in the magnitude of fiscal multipliers is related to country specific effects including the efficiency of the public sector.

The general empirical model used to study the relation between public investment, government efficiency and growth is the following:

$$
\text { growth }_{i t}=a_{0}+a_{1} \text { pub }_{i t}+a_{2} e f f_{i t}+a_{3} p u b_{i t} * e f f_{i t}+\beta \mathrm{X}_{i t}+u_{i t}
$$


where growth $_{i t}$ is the GDP growth rate of country $i$ at time $t, p u b_{i t}$ is the public investment share in GDP and $e_{f f}$ it is a measure of public sector efficiency. We wish to examine whether efficiency of the public sector affects the impact of public investments on growth and, therefore, we include in our model the interaction term of public investments with government efficiency $p u b_{i t}{ }^{*} e f f_{i t} . \quad X$ is a set of other macroeconomic variables which are expected to influence economic growth and $u_{i t}$ is the stochastic disturbance. We follow the literature and include in vector $X$ the variables of private investment, public consumption and trade (exports plus imports), all of them denoted as shares of GDP. We further include the variables of tertiary school enrollment rate, the logarithm of lagged GDP and the lagged growth rates of GDP, to control for convergence effects and dynamic influences of past growth, respectively. Vector $X$ also includes time and country specific effects, in the form of dummy variables, to account for time invariant unobserved heterogeneity and control for common macroeconomic shocks. Two additional dummy variables are included in vector $X$. The first one controls for any regional effects stemming from new EU membership (countries which entered the EU after 2004). The second one accounts for period specific influences to control for the recent financial and economic crisis.

We work with annual data for 28 EU countries which cover the period 20042014. The growth rate of GDP variable is provided by the Penn World Table 8.0 Database. Real GDP of countries is expressed at constant 2005 chained PPP dollars. PWT also provides us with the variables of public consumption and trade, while the variables of public investments and total investment were provided by the National Accounts of Eurostat. Tertiary school enrollment rates were provided by the World Development Indicators. As for the efficiency variable we use several measures of public sector efficiency which were discussed and presented in previous section. 


\subsection{Basic results}

When estimating Equation (3), a possible source of bias could be the existence of unobserved country specific factors which affect growth and are contemporaneously related to policy decisions regarding public investments. In such a case the econometric estimates could be subject to an estimation bias. We have chosen to use the system GMM panel data estimator (see Arellano and Bover 1995; Blundell and Bond 1998) which is the augmented version of the first difference panel data estimator (Arellano and Bond 1991). This estimator eliminates such country specific effects and controls for the presence of endogeneity in covariates included in Equation (3). It has been designed for panel datasets with many panels and few periods as is the case for our model. Instead of the one step estimator, we chose the two step estimator, since it is asymptotically more efficient than the one step estimator and its standard covariance matrix is robust to panel specific autocorrelation and heteroskedasticity. We preferred to use its robust version to get the corrected covariance matrix.

Column 1 reports the results when the identification strategy involves only the variables of public investment, private investment and the lagged growth rates of GDP. Instead of assuming strict exogeneity, we have allowed for endogeneity of the variable of public investment which entails the use of its lagged levels as instruments in the regression. As a rule of thumb for the choice of the number of lags, we chose to keep it at low levels, as a large number of instruments could lead to biased diagnostic tests. Therefore, the public investment variable was instrumented with its once lagged level. The results of the first column clearly suggest that private investment affects positively and significantly economic growth while estimates as regards public investment are not statistically significant. 
Columns 2-7 present econometric estimates after including in the model several variables of public sector efficiency and their interactions with public investment. In particular, Column 2 reports results when the identification strategy includes as explanatory variable for government efficiency the simple average of the sub-indices of infrastructure and stabilization efficiency. Similarly, Columns 3 and 4 show us results of regressions when as explanatory variables are used the efficiency averages of infrastructure, stabilization and education and infrastructure, stabilization, education and administration, respectively. Columns 5-7 show us results when as variables for government efficiency are used the same indicators as those in Columns 2-4 but with a greater weighting for the indicator of infrastructure efficiency. In such a way we put more emphasis on government efficiency in the area of public infrastructure, as it could be considered as a more relevant indicator to study the growth influence of public investments.

We also construct multiplicative terms between public investment and various variables of government efficiency. Given that their correlation might be high, these variables are mean centered (new variables are generated by subtracting their means). In such a way, we are allowed to interpret the coefficient of public investment at the average level of public sector efficiency rather than at the point where efficiency is zero. The results of all columns in Table 3 show that the interaction term enters the estimated equation with a positive and statistically significant coefficient. This implies that in countries where public sector efficiency is high, the growth impact of public investment is superior. The coefficient estimates of the interaction variable range between 0.023 and 0.034 , across various specifications. These point estimates will be used later to assess the growth contribution of public investments at various levels of government efficiency. 
With few exceptions, the estimates of Table 3 confirm that the impact of both public and private investments on growth is positive and statistically significant. The variable of public sector efficiency although positive is not statistically significant in most of regression results reported in Table 3. We also observe that the influence of past growth rates is statistically significant.

The system GMM panel data estimator reports several diagnostic tests. The first one is the Hansen test which tests for the validity of instrumental variables. The hypothesis being tested is that they are uncorrelated with the residuals and therefore are acceptable instruments. The GMM estimator also reports a test for autocorrelation, which is applied to the first differenced residuals. If the null of no autocorrelation is rejected, then the test indicates that lags of the used instruments are in fact endogenous and thus are considered as weak instruments. The results of both tests verify that the instruments are not correlated with the residuals and that no autocorrelation exists in the first differenced residuals.

\subsection{Robustness analysis}

We now examine the robustness of the obtained results by extending the empirical specification in two dimensions. First, we check whether results hold to a variety of econometric specifications. Then, we examine whether estimates remain unchanged when including in the baseline specification alternative measures of public sector efficiency. We first test whether the number of lags, chosen as instruments for the variable of public investment, affects the obtained econometric estimates. Therefore columns 1-6 of Table 4 repeat the econometric estimates of Table 3 (columns 2-7) when the econometric specification includes two lags as instruments for the variable 
of public investment. We observe that econometric estimates of most of the variables included in the econometric specification remain practically unchanged.

We also test whether the inclusion of other relevant macroeconomic variables affects the obtained results. The robustness analysis is conducted on model in Column 5 of Table 3, which is our preferred model specification. In the first four columns of Table 5 we report results when including in the baseline specification the variables of public consumption ( $\%$ of GDP), volume of trade ( $\%$ of GDP), the lagged level of GDP and the variable of tertiary school enrolment rate. In the last two columns we report results after treating the variables of public sector efficiency and private investment as endogenously determined, as they might be affected by past outcomes of growth or may be correlated with the error term. The econometric estimates of all columns shown in Table 5 confirm the initially obtained estimates as regards the sign and statistical significance of the interaction term between public investment and government efficiency.

Next we examine whether results hold to a variety of sub-indicators of government efficiency. Table 6 presents estimates when using in the baseline econometric specification the indices of government efficiency in the areas of administration, stabilization, education and infrastructure. Although reported estimates on the variables of public investment and government efficiency are not statistically significant, their multiplicative term is positive and statistically significant for most of indicators used, except that of efficiency in the area of public administration.

Finally, we follow stochastic frontier analysis as an alternative way to obtain measures of government efficiency. We base our analysis on the model specification 
of Battese and Coelli (1995) in which a technical inefficiency model is simultaneously estimated with a stochastic frontier model at one stage.

For each of the four public policy areas, we model for the existence of unobserved inefficiency within the following log linear stochastic frontier model:

$$
\ln Y_{i t}=\beta_{0}+\beta_{1} \ln X_{i t}+V_{i t}-U_{i t}
$$

$Y_{i t}$ is a measure of public sector performance in country $i$ at time $t$ in one of the four key policies areas discussed previously (administration, stabilization, education and infrastructure). $X_{i t}$ is the associated variable of government spending required as input in the public sector. $V_{i t}$ and $U_{i t}$ are the two components of the error structure. $V_{i t}$ is the noise residual assumed to be identically distributed and independent of $U_{i t}$. $U_{i t}$ is the nonnegative component of the error term, associated with technical inefficiency and following an asymmetric distribution of the upper half of the normal distribution.

Along with the log linear stochastic frontier, we jointly estimate the following technical inefficiency model:

$$
\mu_{i t}=\delta_{0}+\delta_{1} X_{i t}+W_{i t}
$$

where $\mu_{i t}$ is the mean of the truncated distribution of $U_{i t}$ which is associated with inefficiency. $X_{i t}$ includes dummies to control for unobserved country specific and time specific influences on inefficiency. $W_{i t}$ is a random variable, defined by the truncation of the normal distribution.

All parameters included in the log linear specification of equation (4) along with the technical inefficiency model (5) are estimated simultaneously at one stage by using maximum likelihood. After estimating equations (4) and (5), a measure for public sector efficiency in each country $i$ at time $t$ is obtained by:

$$
T E_{i t}=\exp \left\{-U_{i t}\right\}
$$


which is a non negative variable between zero and one. The efficiency scores for each policy area are shown Table 7 . We also provide two measures for total public sector efficiency, the first one by attributing equal weights to each policy area and the second by giving a higher weighting to the efficiency index of public infrastructures. We observe that rankings of countries obtained after using these efficiency indicators do not differ substantially to those shown in Table 2. In Table 8 we report econometric results based on these efficiency indicators. The multiplicative term between public investment and government efficiency remains positive but is statistically significant only for the regression in which the equal weights' efficiency indicator is used.

\subsection{Discussion}

The interpretation of the main coefficient of public investment $\left(a_{1}\right)$ is its effect on growth when the level of public efficiency is zero. This becomes evident when taking the partial derivative of equation (3) with respect to public investment:

$$
\frac{\partial\left(\text { growth }_{i t}\right)}{\partial\left(p u b_{i t}\right)}=\alpha_{1}+\alpha_{3} * e f f_{i t} \text { (7) }
$$

Similarly, when estimating a model with interaction terms, the resulting output of standard errors is misleading. We re-calculate standard errors of public investment conditional on various levels public sector efficiency $\left(e f f=x_{j}\right)$ with the following formula:

$$
s_{a_{1}+a_{3} e f f \mid e f f=x_{j}}=\left(\operatorname{var}\left[a_{1}\right]+x_{j}^{2} \operatorname{var}\left[a_{3}\right]+2 x_{1} \operatorname{cov}\left[a_{1}, a_{3}\right]\right)^{\frac{1}{2}}
$$

The variances and co-variance in (8) are directly obtained from the variancecovariance matrix in the original output. 
We get a more realistic insight into the influence of public investments on growth by using equations (7-8) as well as regression results reported in Table 3 (column 2). Figure 2 provides us with estimates of the growth contribution of public investment (vertical axis) at various levels of public sector efficiency (horizontal axis) along with its two standard error confidence intervals.

We observe that for the whole spectrum of observations, the impact of public investments is statistically significant and its growth contribution ranges between 0.03 and 0.16. As the level of public sector efficiency increases the growth impact of public investment also rises implying that government efficiency really matters when assessing the growth contribution of public investments. The main policy conclusion to be drawn from this study is that governments should place more emphasis on the effective and transparent allocation of their resources as away to increase their efficiency. This will bring about more rational choices regarding public investments and would in turn result to higher effects on aggregate economic growth.

\section{Concluding remarks}

The purpose of this study was to examine whether differences in public sector efficiency is an important element for assessing the influence of public investment on growth of EU countries. The associated fiscal multipliers differ substantially from country to country while the econometric results show that the efficiency of public sector indeed matters in raising the influence of public investment on growth. This result remains robust to several changes in the econometric specification and to various measures of government efficiency used as explanatory variables in the econometric estimations. 
The impact of fiscal policy on growth is still an open issue. Further research may focus on whether country specific factors such as monetary policy, trade openness or the level of development affect the growth influence of either public spending or taxes.

\section{References}

Afonso, A., Schuknecht, L., Tanzi, V., 2005, Public sector efficiency: an international comparison, Public Choice 123:321-347.

Alesina, A., Ardagna, S., 2010, Large changes in fiscal policy: taxes versus spending In: Brown, J., (ed.), Tax Policy and the Economy, pp. 35-68.

Angelopoulos, K., Philippopoulos, A., Tsionas, M., 2008, Does public sector efficiency matter? Revisiting the relation between fiscal size and economic growth in a world sample, Public Choice 137: 245-278.

Arellano, M., Bond, S., 1991, Some tests of specification for panel data: Monte Carlo evidence and an application to employment equations, Review of Economic Studies 58: $277-297$.

Arellano, M., Bover, O., 1995, Another look at the instrumental variable estimation of error-components models, Journal of Econometrics 68: 29-51.

Battese, G., Coelli, T., 1995, A model for technical inefficiency effects in a stochastic frontier production function for panel data, Empirical Economics 20: 325-32.

Baxter, M., King, R., 1993, Fiscal policy in general equilibrium, American Economic Review 83: 315-334. 
Blanchard, O., Perotti, R., 2002, An empirical characterization of the dynamic effects of changes in government spending and taxes on output, Quarterly Journal of Economics 117: 1329-1368.

Blundell, R., Bond. S., 1998, Initial conditions and moment restrictions in dynamic panel data models, Journal of Econometrics 87: 115-43.

Burnside, C., Eichenbaum, M., Fisher, J., 2004, Fiscal shocks and their consequences, Journal of Economic Theory 115: 89-117.

Christiano, L., Eichenbaum, M., Rebelo, S., 2011, When is the government spending multiplier large? Journal of Political Economy 119: 78-121.

Chung, H., Leeper, M., 2007, What has financed government debt? NBER Working Paper No. 13425.

Cogan, J.F., Cwik, T., Taylor, J.B., Wieland, V., 2010, New Keynesian versus old Keynesian government spending multipliers, Journal of Economic Dynamics and Control 34: 281-295.

Economic Freedom of the World, 2015, Annual Report, Fraser Institute.

Eurostat, 2014, National Accounts Database.

Favero, C., Giavazzi, F., 2007, Debt and the effects of fiscal policy, NBER Working Paper No. 12822.

Feenstra, R., Inklaar, R,, Timmer, M., 2013, The next generation of the Penn World Table. Available at: www.ggdc.net/pwt.

Gali, J., Lopez-Salido, J.D., Valles, J., 2007, Understanding the effects of government spending on consumption, Journal of the European Economic Association 5: 227-270. Hall, R.E., 2009, By how much does GDP rise if the government buys more output? Brookings Papers on Economic Activity 40: 183-249. 
Ilzetzaki, E., Mendoza, G., Vegh, C., 2013, How big (small) are fiscal multipliers? Journal of Monetary Economics 60: 239-254.

Monacelli, T., Perotti, R., 2008, Fiscal policy, wealth effects and markups, NBER Working Paper No. 14584.

Monacelli, T., Perotti, R., Trigari, A., 2010, Unemployment fiscal multipliers, Journal of Monetary Economics 57: 531-553.

Mountford, A., Uhlig, H., 2009, What are the effects of fiscal policy shocks? Journal of Applied Econometrics 24: 960-992.

Perotti, R., 1999, Fiscal policy in good times and bad, Quarterly Journal of Economics 114: $1399-1436$.

Perotti, R., 2005, Estimating the effects of fiscal policy in OECD countries, Proceedings, Federal Reserve Bank of San Francisco.

Perotti, R., 2007, In search of the transmission mechanism of fiscal policy, NBER Macroeconomics Annual 22: 169-226.

Ramey, V., 2011, Identifying government expenditure shocks: it is all in the timing, Quarterly Journal of Economics 126: 1-50.

Transparency International, 2015, Corruption Perceptions Index, Annual Reports.

Van den Noord, P., 2000, The size and role of automatic fiscal stabilizers in the 1990s and beyond, OECD Economics Department Working Paper No. 230.

Veld J., Larch M.,Vandeweyer M., 2012, Automatic fiscal stabilizers: what they are and what they do, European Economy Economic Paper No.452, European Commission.

World Development Indicators, 2015, World Bank. 


\section{Appendix}

Relying on Blanchard and Perotti (2002) and Perotti (2005), the reduced form residuals for government consumption $u_{t}^{g c}$, government investment $u_{t}^{g i}$ and taxes $u_{t}^{t}$ can be expressed as a linear function of: (a) automatic responses to movements in the macroeconomic variables of GDP, prices and interest rate, (b) discretionary response of fiscal policy to macroeconomic news and (c) random exogenous fiscal policy shocks $\left(e_{t}^{g c}, e_{t}^{g i}, e_{t}^{t}\right)$. The latter components are the structural shocks in government consumption, government investment and taxes that we try to indentify in order to measure responses of output. The reduced form residuals for government consumption $u_{t}^{g c}$, public investment $u_{t}^{g i}$, and net taxes $u_{t}^{t}$ can be represented as:

$$
\begin{gathered}
u_{t}^{g c}=a_{g c, y} u_{t}^{y}+a_{g c, p} u_{t}^{p}+a_{g c, r} u_{t}^{r}+\beta_{g c, t} e_{t}^{t}+e_{t}^{g c} \\
u_{t}^{g i}=a_{g i, y} u_{t}^{y}+a_{g i, p} u_{t}^{p}+a_{g i, r} u_{t}^{r}+\beta_{g i, t} e_{t}^{t}+e_{t}^{g i} \\
u_{t}^{t}=a_{t, y} u_{t}^{y}+a_{t, p} u_{t}^{p}+a_{t, r} u_{t}^{r}+\beta_{t, g c} e_{t}^{g c}+e_{t}^{t}
\end{gathered}
$$

In order to recover structural residuals from the reduced form VAR, we need to have estimates for the $a_{i, j}$ 's and $\beta_{i, j}$ 's. The use of quarterly data allows us to set the contemporaneous response of discretionary fiscal policy to innovations in GDP, prices and interest rate equal to zero, since it takes more than a quarter to approve and implement new measures. Therefore, the $a_{i, j}$ 's coefficients in equations (A1), (A2) and (3) only reflect automatic responses of fiscal variables to movements in variables of GDP, prices and interest rate.

The output elasticities of government spending $a_{g c, y}$ and government investment $a_{g i, y}$ are set equal to zero, as there is no evidence in favor of any substantial response of these components to changes in GDP, within one quarter. Following Perotti (2005), the price elasticities of government consumption and public 
investment, $a_{g c, p}$ and $a_{g i, p}$, are set equal to 0.5 , as several components of government spending are related to changes in prices (i.e. purchases of goods and services, wages). Also, given that the definitions of government spending and taxes do not contain interest rate payments, their interest rate elasticities are zero. The output elasticities of net taxes have been obtained from Veld et al. (2012). ${ }^{4}$ The price elasticity of taxes has been constructed as the weighted average of the individual elasticities of four broad tax categories: indirect taxes, social security contributions and direct personal and corporate taxes. However, we follow Perotti (2005) and set the price elasticities of indirect taxes and corporate taxes equal to zero. The price elasticities of personal income taxes and social security contributions have been obtained from Van den Noord (2000). ${ }^{5}$

Once output and price elasticities have been obtained, the fiscal shocks can be expressed in the following way:

$$
\begin{gathered}
u_{t}^{g c}-a_{g c, y} u_{t}^{y}-a_{g c, p} u_{t}^{p}-a_{g c, r} u_{t}^{r}=\beta_{g c, t} e_{t}^{t}+e_{t}^{g c} \\
u_{t}^{g i}-a_{g i, y} u_{t}^{y}-a_{g i, p} u_{t}^{p}-a_{g i, r} u_{t}^{r}=\beta_{g i, t} e_{t}^{t}+e_{t}^{g i} \\
u_{t}^{t}-a_{t, y} u_{t}^{y}-a_{t, p} u_{t}^{p}-a_{t, r} u_{t}^{r}=\beta_{t, g c} e_{t}^{g c}+e_{t}^{t}
\end{gathered}
$$

Since there is no a priori knowledge on whether decisions for spending are before decisions for taxes or the opposite, we have assumed that spending decisions come first and taxes follow and therefore $\beta_{g c, t}=\beta_{g i, t}=0$.

The reduced form residuals for GDP are a linear combination of fiscal variable shocks:

$$
u_{t}^{y}=\gamma_{y, g c} u_{t}^{g c}+\gamma_{y, g i} u_{t}^{g i}+\gamma_{y, t} u_{t}^{t}+e_{t}^{y} \quad(\mathrm{~A} 7)
$$

\footnotetext{
${ }^{4}$ In countries for which we do not have available the elasticities of taxes to GDP, we use the average of the Euro area countries.

${ }^{5}$ In countries for which we do not have estimates for price elasticities of taxes, we use the average of the EU countries.
} 
Accordingly, the reduced form residuals for price changes and interest rates are expressed as:

$$
\begin{gathered}
u_{t}^{p}=\gamma_{p, g c} u_{t}^{g c}+\gamma_{p, g i} u_{t}^{g i}+\gamma_{p, t} u_{t}^{t}+\gamma_{p, y} u_{t}^{y}+e_{t}^{p} \\
u_{t}^{r}=\gamma_{r, g c} u_{t}^{g c}+\gamma_{r, g i} u_{t}^{g i}+\gamma_{r, t} u_{t}^{t}+\gamma_{r, y} u_{t}^{y}+\gamma_{r, p} u_{t}^{p}+e_{t}^{r}
\end{gathered}
$$

The final econometric specification can be written as:

$$
A U_{t}=B V_{t}(\mathrm{~A} 10)
$$

where $V_{t} \equiv\left(e_{t}^{g c}, e_{t}^{g i} e_{t}^{t}, e_{t}^{y}, e_{t}^{p}, e_{t}^{r}\right)$ is the vector including orthogonal structural shocks, with: $A=\left[\begin{array}{cccccc}1 & 0 & 0 & 0 & -a_{g c, p} & 0 \\ 0 & 1 & 0 & 0 & -a_{g i, p} & 0 \\ 0 & 0 & 1 & -a_{t, y} & -a_{t, p} & 0 \\ -\gamma_{y, g c} & -\gamma_{y, g i} & -\gamma_{y, t} & 1 & 0 & 0 \\ -\gamma_{p, g c} & -\gamma_{p, g i} & -\gamma_{p, t} & -\gamma_{p, y} & 1 & 0 \\ -\gamma_{r, g c} & -\gamma_{r, g i} & -\gamma_{r, t} & -\gamma_{r, y} & -\gamma_{r, p} & 1\end{array}\right]$ an $B=\left[\begin{array}{cccccc}1 & 0 & 0 & 0 & 0 & 0 \\ 0 & 1 & 0 & 0 & 0 & 0 \\ \beta_{t, g c} & \beta_{t, g i} & 1 & 0 & 0 & 0 \\ 0 & 0 & 0 & 1 & 0 & 0 \\ 0 & 0 & 0 & 0 & 1 & 0 \\ 0 & 0 & 0 & 0 & 0 & 1\end{array}\right]$ 
Tables and figures

Figure 1 Public investment across EU countries (2014, \% GDP)

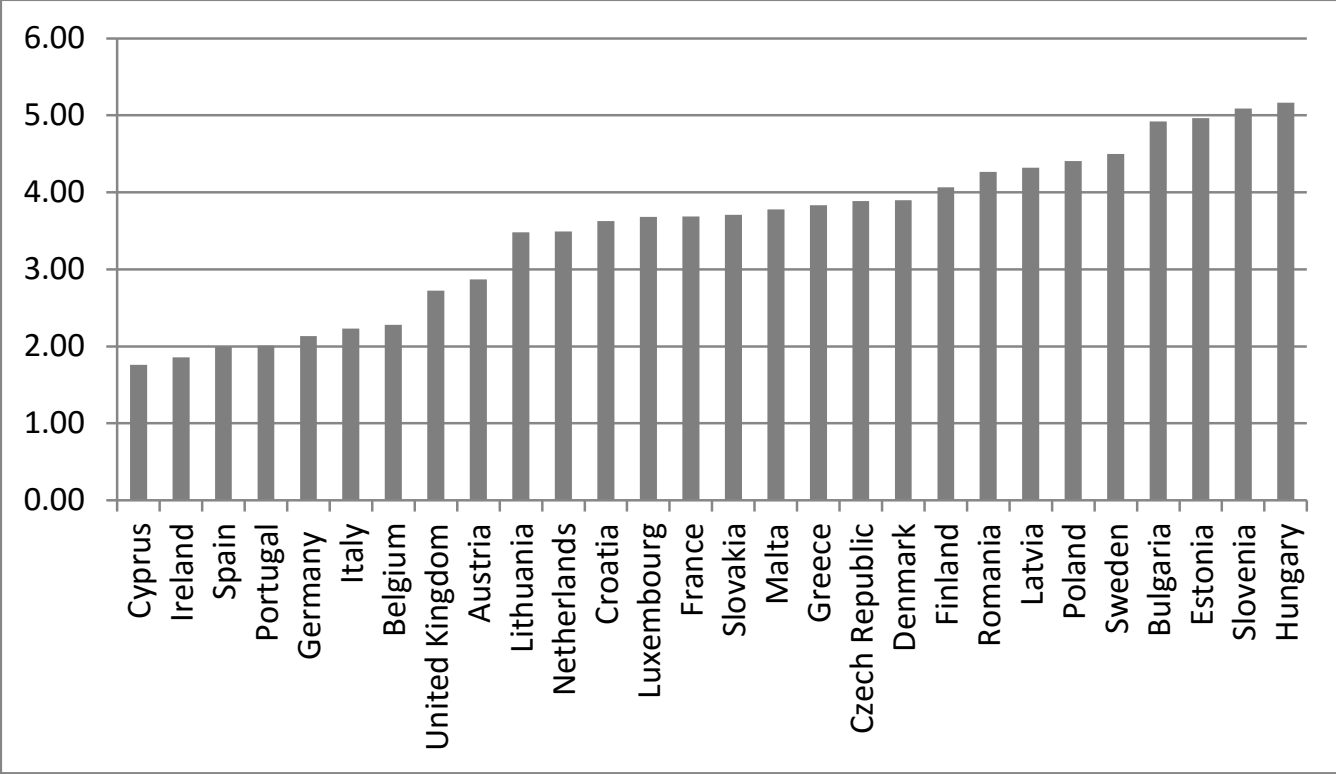

Source: Eurostat, National Accounts. 
Table 1 Public investment multipliers

\begin{tabular}{|l|c|c|c|c|}
\hline & $\mathrm{Q} 1$ & $\mathrm{Q} 2$ & $\mathrm{Q} 3$ & $\mathrm{Q} 4$ \\
\hline Lithuania & -0.48 & -0.90 & -1.71 & -2.72 \\
\hline Latvia & -0.15 & -0.67 & -1.20 & -1.77 \\
\hline Hungary & -0.06 & -0.32 & -0.70 & -1.14 \\
\hline Ireland & -0.06 & -0.20 & -0.71 & -1.04 \\
\hline Cyprus & -0.13 & -0.29 & -0.42 & -0.69 \\
\hline Belgium & -0.03 & -0.32 & -0.47 & -0.67 \\
\hline Spain & -0.02 & -0.11 & -0.28 & -0.52 \\
\hline Romania & -0.05 & -0.11 & -0.25 & -0.42 \\
\hline Finland & -0.65 & -1.06 & -1.04 & -0.36 \\
\hline Poland & -0.05 & -0.08 & -0.14 & -0.32 \\
\hline Portugal & 0.10 & 0.02 & -0.09 & -0.26 \\
\hline Bulgaria & 0.030 & -0.14 & -0.21 & -0.16 \\
\hline Denmark & -0.14 & -0.10 & 0.02 & 0.21 \\
\hline France & -0.52 & -0.57 & -0.28 & 0.48 \\
\hline Czech Republic & 0.02 & 0.10 & 0.30 & 0.50 \\
\hline Slovakia & -0.07 & -0.04 & 0.20 & 0.51 \\
\hline Malta & -0.01 & 0.19 & 0.39 & 0.63 \\
\hline United Kingdom & 0.07 & 0.17 & 0.36 & 0.63 \\
\hline Sweden & 0.19 & 0.20 & 0.54 & 0.76 \\
\hline Greece & 0.08 & 0.40 & 0.59 & 1.13 \\
\hline Estonia & 0.32 & 0.83 & 1.25 & 1.39 \\
\hline Italy & 0.08 & 0.26 & 0.68 & 1.39 \\
\hline Austria & -0.09 & 0.39 & 0.87 & 1.43 \\
\hline Slovenia & 0.25 & 0.69 & 1.18 & 1.57 \\
\hline Netherlands & 0.20 & 0.47 & 1.07 & 1.69 \\
\hline Luxembourg & 0.96 & 1.70 & 1.83 & 1.71 \\
\hline Germany & 0.73 & 1.42 & 2.08 \\
\hline
\end{tabular}

*Countries are ordered in ascending order of the public investment multiplier. 
Table 2 Public sector efficiency indicators

\begin{tabular}{|c|c|c|c|c|c|}
\hline & $\begin{array}{l}\text { Administration } \\
\text { index (2013) }\end{array}$ & $\begin{array}{l}\text { Stabilization } \\
\text { index (2014) }\end{array}$ & $\begin{array}{c}\text { Education } \\
\text { index (2013) }\end{array}$ & $\begin{array}{l}\text { Infrastructure } \\
\text { index (2014) }\end{array}$ & $\begin{array}{c}\text { Total Index } \\
(2013) \\
\end{array}$ \\
\hline Bulgaria & 0.41 & 0.29 & 0.73 & 0.46 & 0.58 \\
\hline Slovakia & 0.53 & -0.87 & 0.69 & 0.58 & 0.65 \\
\hline Hungary & 0.62 & 0.19 & 0.65 & 0.48 & 0.66 \\
\hline Croatia & 0.63 & -0.20 & 0.87 & 0.67 & 0.68 \\
\hline Romania & 0.62 & 0.34 & 0.56 & 0.44 & 0.72 \\
\hline Lithuania & 0.71 & 1.32 & 0.90 & 0.67 & 0.76 \\
\hline Latvia & 0.80 & 0.66 & 0.91 & 0.51 & 0.78 \\
\hline Poland & 0.86 & 1.58 & 1.03 & 0.51 & 0.86 \\
\hline Estonia & 0.96 & -0.02 & 0.97 & 0.58 & 0.87 \\
\hline Czech Republic & 0.67 & 1.07 & 0.81 & 0.59 & 0.88 \\
\hline Malta & 0.82 & 1.06 & 0.54 & 0.81 & 0.96 \\
\hline Sweden & 1.16 & 0.07 & 0.86 & 0.70 & 0.98 \\
\hline Cyprus & 1.17 & 0.36 & 0.84 & 1.24 & 0.99 \\
\hline Slovenia & 0.86 & 1.27 & 1.37 & 0.50 & 1.00 \\
\hline Portugal & 1.06 & -0.01 & 1.06 & 1.42 & 1.02 \\
\hline Spain & 0.92 & -0.61 & 1.47 & 1.67 & 1.09 \\
\hline Italy & 0.91 & 1.13 & 1.15 & 1.49 & 1.13 \\
\hline Greece & 0.88 & 0.16 & 2.23 & 0.71 & 1.14 \\
\hline Finland & 1.37 & 0.69 & 1.30 & 0.69 & 1.15 \\
\hline France & 1.14 & 0.74 & 0.89 & 1.67 & 1.15 \\
\hline Denmark & 1.28 & 0.94 & 1.13 & 0.73 & 1.16 \\
\hline Belgium & 1.31 & 1.04 & 1.16 & 1.74 & 1.40 \\
\hline Netherlands & 1.19 & 0.84 & 1.05 & 2.02 & 1.41 \\
\hline United Kingdom & 1.48 & 1.12 & 0.99 & 2.75 & 1.70 \\
\hline Luxembourg & 1.85 & 1.55 & 0.43 & 2.04 & 1.73 \\
\hline Ireland & 2.25 & 1.81 & 1.80 & 1.52 & 1.76 \\
\hline Austria & 1.66 & 1.66 & 1.71 & 1.12 & 1.92 \\
\hline Germany & 1.58 & 1.49 & 1.12 & 3.95 & 2.26 \\
\hline
\end{tabular}

*Countries are ranked in ascending order of the total public sector efficiency index.**Scores for the administration index end in 2013, for the stabilization index in 2014, for the education index in 2013, for the infrastructure index in 2014 and for the total index in 2013. 
Table 3 System GMM Econometric Estimates (Basic results)

\begin{tabular}{|c|c|c|c|c|c|c|c|}
\hline \multicolumn{8}{|c|}{ Dependent variable: Growth rate of GDP } \\
\hline & (1) & (2) & (3) & (4) & (5) & (6) & (7) \\
\hline Public investment & $\begin{array}{l}0.012 \\
(1.29)\end{array}$ & $\begin{array}{l}0.020 * * \\
(1.97)\end{array}$ & $\begin{array}{c}0.020 * * \\
(2.05)\end{array}$ & $\begin{array}{c}0.020 * * \\
(2.38)\end{array}$ & $\begin{array}{c}0.019 * * \\
(2.53)\end{array}$ & $\begin{array}{l}0.014 \\
(1.23)\end{array}$ & $\begin{array}{l}0.011 \\
(0.88)\end{array}$ \\
\hline Efficiency & & $\begin{array}{l}0.050 \\
(1.41)\end{array}$ & $\begin{array}{r}0.077^{*} \\
(1.85)\end{array}$ & $\begin{array}{l}0.078 \\
(1.59)\end{array}$ & $\begin{array}{l}0.041 \\
(1.45)\end{array}$ & $\begin{array}{l}0.051 \\
(1.29)\end{array}$ & $\begin{array}{l}0.050 \\
(1.41)\end{array}$ \\
\hline $\begin{array}{l}\text { Public investment* } \\
\text { Efficiency }\end{array}$ & & $\begin{array}{c}0.024 * * \\
(2.51)\end{array}$ & $\begin{array}{c}0.023 * * \\
(2.36)\end{array}$ & $\begin{array}{c}0.024 * * \\
(2.18)\end{array}$ & $\begin{array}{c}0.034 * * \\
(2.02)\end{array}$ & $\begin{array}{l}0.029 * * \\
(2.04)\end{array}$ & $\begin{array}{c}0.034 * * \\
(1.98)\end{array}$ \\
\hline Private investment & $\begin{array}{c}0.008 * * \\
(3.07)\end{array}$ & $\begin{array}{l}0.004 \\
(0.90)\end{array}$ & $\begin{array}{c}0.012 * * \\
(3.43)\end{array}$ & $\begin{array}{r}0.008^{*} \\
(1.69)\end{array}$ & $\begin{array}{r}0.009^{*} \\
(1.86)\end{array}$ & $\begin{array}{c}0.011 * * \\
(2.67)\end{array}$ & $\begin{array}{c}0.013 * * \\
(2.26)\end{array}$ \\
\hline $\begin{array}{l}\text { Growth rate of } \\
\text { GDP }(-1)\end{array}$ & $\begin{array}{l}-0.161 \\
(-0.54)\end{array}$ & $\begin{array}{l}-0.441 \\
(-0.97)\end{array}$ & $\begin{array}{c}-0.685 * * \\
(-1.99)\end{array}$ & $\begin{array}{l}-0.544 \\
(-1.49)\end{array}$ & $\begin{array}{l}-0.349 \\
(-0.75)\end{array}$ & $\begin{array}{l}-0.474 \\
(-1.23)\end{array}$ & $\begin{array}{l}-0.139 \\
(-0.95)\end{array}$ \\
\hline $\begin{array}{l}\text { Growth rate of } \\
\text { GDP }(-2)\end{array}$ & $\begin{array}{r}-0.485^{*} \\
(-1.66)\end{array}$ & $\begin{array}{l}-0.361 \\
(-1.04)\end{array}$ & $\begin{array}{c}-0.837 * * \\
(-3.50)\end{array}$ & $\begin{array}{l}-0.541^{*} \\
(-1.71)\end{array}$ & $\begin{array}{l}-0.666 \\
(-1.54)\end{array}$ & $\begin{array}{l}-0.672^{*} \\
(-1.78)\end{array}$ & $\begin{array}{c}-0.802 * * \\
(-1.96)\end{array}$ \\
\hline Constant & $\begin{array}{c}-0.160 * * \\
(-2.74)\end{array}$ & $\begin{array}{l}-0.195 \\
(-1.57)\end{array}$ & $\begin{array}{c}-0.375^{* *} \\
(-3.69)\end{array}$ & $\begin{array}{c}-0.302 * * \\
(-3.07)\end{array}$ & $\begin{array}{c}-0.246 * * \\
(-2.09)\end{array}$ & $\begin{array}{c}-0.298^{* *} \\
(-2.81)\end{array}$ & $\begin{array}{c}-0.310^{* *} \\
(-2.61)\end{array}$ \\
\hline $\begin{array}{l}\text { Country Fixed } \\
\text { Effects }\end{array}$ & Yes & Yes & Yes & Yes & Yes & Yes & Yes \\
\hline Time Effects & Yes & Yes & Yes & Yes & Yes & Yes & Yes \\
\hline $\begin{array}{l}\text { Hansen test (p- } \\
\text { value) }{ }^{\dagger \dagger}\end{array}$ & $\begin{array}{l}14.44 \\
(0.49)\end{array}$ & $\begin{array}{c}9.11 \\
(0.76)\end{array}$ & $\begin{array}{c}7.54 \\
(0.82)\end{array}$ & $\begin{array}{c}8.25 \\
(0.76)\end{array}$ & $\begin{array}{l}10.14 \\
(0.68)\end{array}$ & $\begin{array}{c}8.13 \\
(0.77)\end{array}$ & $\begin{array}{c}7.77 \\
(0.80)\end{array}$ \\
\hline $\begin{array}{l}\text { Autocor. Test (p- } \\
\text { value) }\end{array}$ & $\begin{array}{c}0.92 \\
(0.36)\end{array}$ & $\begin{array}{l}0.05 \\
(0.96)\end{array}$ & $\begin{array}{c}0.72 \\
(0.47)\end{array}$ & $\begin{array}{c}0.29 \\
(0.77)\end{array}$ & $\begin{array}{c}0.56 \\
(0.57)\end{array}$ & $\begin{array}{c}0.46 \\
(0.64)\end{array}$ & $\begin{array}{c}0.81 \\
(0.41)\end{array}$ \\
\hline Observations & 308 & 308 & 280 & 280 & 308 & 280 & 280 \\
\hline
\end{tabular}

$\dagger$ The z-statistics are reported in parentheses. $\dagger \dagger$ The null hypothesis is that the instruments used in the regression are valid. $\dagger \dagger \dagger$ The null hypothesis is that the errors in the first-differenced regression exhibit no second order serial correlation.** Significant at the 5\% level. * Significant at the 10 level. 
Table 4 System GMM Econometric Estimates (robustness-number of lags)

\begin{tabular}{|c|c|c|c|c|c|c|}
\hline \multicolumn{7}{|c|}{ Dependent variable: Growth rate of GDP } \\
\hline & (1) & (2) & (3) & (4) & (5) & (6) \\
\hline Public investment & $\begin{array}{c}0.024 * * \\
(2.02)\end{array}$ & $\begin{array}{r}0.016^{*} \\
(1.91)\end{array}$ & $\begin{array}{l}0.018^{*} \\
(1.83)\end{array}$ & $\begin{array}{r}0.029 * \\
(1.77)\end{array}$ & $\begin{array}{l}0.015 \\
(1.63)\end{array}$ & $\begin{array}{l}0.017 \\
(1.51)\end{array}$ \\
\hline Efficiency & $\begin{array}{c}0.056^{* *} \\
(2.91)\end{array}$ & $\begin{array}{l}0.066 \\
(1.44)\end{array}$ & $\begin{array}{l}0.085 \\
(1.47)\end{array}$ & $\begin{array}{l}0.045 \\
(1.20)\end{array}$ & $\begin{array}{l}0.062 \\
(1.38)\end{array}$ & $\begin{array}{l}0.067 \\
(1.35)\end{array}$ \\
\hline $\begin{array}{l}\text { Public investment* } \\
\text { Efficiency }\end{array}$ & $\begin{array}{l}0.020 * * \\
(3.46)\end{array}$ & $\begin{array}{c}0.023 * * \\
(4.42)\end{array}$ & $\begin{array}{c}0.021 * * \\
(2.49)\end{array}$ & $\begin{array}{c}0.014 * * \\
(2.03)\end{array}$ & $\begin{array}{c}0.018 * * \\
(2.77)\end{array}$ & $\begin{array}{r}0.017 * \\
(1.93)\end{array}$ \\
\hline Private investment & $\begin{array}{c}0.008 * * \\
(2.11)\end{array}$ & $\begin{array}{l}0.044 \\
(0.88)\end{array}$ & $\begin{array}{l}0.010^{*} \\
(1.94)\end{array}$ & $\begin{array}{l}0.005 \\
(1.40)\end{array}$ & $\begin{array}{c}0.010^{* *} \\
(3.06)\end{array}$ & $\begin{array}{c}0.008 * * \\
(2.46)\end{array}$ \\
\hline Growth rate of GDP $(-1)$ & $\begin{array}{c}-0.901 * * \\
(-3.65)\end{array}$ & $\begin{array}{l}-0.516 \\
(-1.55)\end{array}$ & $\begin{array}{r}-0.693 * \\
(-1.82)\end{array}$ & $\begin{array}{r}-0.744^{*} \\
(-1.94)\end{array}$ & $\begin{array}{c}-0.744 * * \\
(-2.30)\end{array}$ & $\begin{array}{r}-0.683^{*} \\
(-1.86)\end{array}$ \\
\hline Growth rate of GDP $(-2)$ & $\begin{array}{l}-0.338 \\
(-1.30) \\
\end{array}$ & $\begin{array}{l}-0.444 \\
(-1.31) \\
\end{array}$ & $\begin{array}{l}-0.437 \\
(-1.27) \\
\end{array}$ & $\begin{array}{l}-0.281 \\
(-1.09) \\
\end{array}$ & $\begin{array}{c}-0.554 * * \\
(-2.24) \\
\end{array}$ & $\begin{array}{r}-0.495^{*} \\
(-1.73) \\
\end{array}$ \\
\hline Constant & $\begin{array}{c}-0.306 * * \\
(-4.06)\end{array}$ & $\begin{array}{l}-0.188 \\
(-1.63)\end{array}$ & $\begin{array}{c}-0.335 * * \\
(-3.35)\end{array}$ & $\begin{array}{c}-0.254^{*} \\
(-1.75)\end{array}$ & $\begin{array}{c}-0.288 * * \\
(-2.89)\end{array}$ & $\begin{array}{c}-0.270 * * \\
(-2.48)\end{array}$ \\
\hline Country Fixed Effects & Yes & Yes & Yes & Yes & Yes & Yes \\
\hline Time Effects & Yes & Yes & Yes & Yes & Yes & Yes \\
\hline Hansen test $(\mathrm{p} \text {-value })^{\dagger \dagger}$ & $\begin{array}{c}6.21 \\
(1.00)\end{array}$ & $\begin{array}{c}8.79 \\
(0.99)\end{array}$ & $\begin{array}{l}11.90 \\
(0.96)\end{array}$ & $\begin{array}{l}11.04 \\
(0.98)\end{array}$ & $\begin{array}{c}9.99 \\
(0.98)\end{array}$ & $\begin{array}{l}11.70 \\
(0.96)\end{array}$ \\
\hline Autocor. Test (p-value) ${ }^{\dagger \dagger \dagger}$ & $\begin{array}{l}-2.01 \\
(0.04)\end{array}$ & $\begin{array}{c}0.22 \\
(0.82)\end{array}$ & $\begin{array}{l}-0.38 \\
(0.70)\end{array}$ & $\begin{array}{l}-1.02 \\
(0.31)\end{array}$ & $\begin{array}{l}-0.24 \\
(0.81)\end{array}$ & $\begin{array}{l}-0.09 \\
(0.92)\end{array}$ \\
\hline Observations & 308 & 280 & 280 & 308 & 280 & 280 \\
\hline
\end{tabular}

$\dagger$ The $z$-statistics are reported in parentheses. †† The null hypothesis is that the instruments used in the regression are valid. $\dagger \dagger \dagger$ The null hypothesis is that the errors in the first-differenced regression exhibit no second order serial correlation. ** Significant at the 5\% level. * Significant at the $10 \%$ level. 
Table 5 System GMM Econometric Estimates (Different econometric specifications)

\begin{tabular}{|c|c|c|c|c|c|c|}
\hline \multicolumn{7}{|c|}{ Dependent variable: Growth rate of GDP } \\
\hline & $\begin{array}{c}\text { Public } \\
\text { consumption }\end{array}$ & Trade & $\begin{array}{l}\text { Initial } \\
G D P\end{array}$ & $\begin{array}{c}\text { Tertiary } \\
\text { school } \\
\text { enrollment } \\
\text { rate }\end{array}$ & $\begin{array}{l}\text { Endogenous } \\
\text { efficiency }\end{array}$ & $\begin{array}{c}\text { Endogenous } \\
\text { private } \\
\text { investment }\end{array}$ \\
\hline Public investment & $\begin{array}{l}0.012 \\
(0.60)\end{array}$ & $\begin{array}{l}0.021 * * \\
(2.34)\end{array}$ & $\begin{array}{c}0.023 * * \\
(3.25)\end{array}$ & $\begin{array}{l}0.009 \\
(0.79)\end{array}$ & $\begin{array}{l}-0.017 \\
(-0.72)\end{array}$ & $\begin{array}{l}-0.010 \\
(-0.57)\end{array}$ \\
\hline Efficiency & $\begin{array}{l}0.058 \\
(0.77) \\
\end{array}$ & $\begin{array}{c}0.093 * * \\
(2.29) \\
\end{array}$ & $\begin{array}{c}0.107 * * \\
(2.14) \\
\end{array}$ & $\begin{array}{l}0.076 \\
(1.57) \\
\end{array}$ & $\begin{array}{r}0.0009 \\
(0.02) \\
\end{array}$ & $\begin{array}{l}-0.002 \\
(-0.05) \\
\end{array}$ \\
\hline $\begin{array}{l}\text { Public } \\
\text { investment*Efficiency }\end{array}$ & $\begin{array}{c}0.025 * * \\
(2.11)\end{array}$ & $\begin{array}{c}0.024 * * \\
(3.92)\end{array}$ & $\begin{array}{c}0.027 * * \\
(3.18)\end{array}$ & $\begin{array}{c}0.043 * * \\
(4.57)\end{array}$ & $\begin{array}{c}0.039 * * \\
(2.35)\end{array}$ & $\begin{array}{c}0.029 * * \\
(2.49)\end{array}$ \\
\hline Private investment & $\begin{array}{l}0.009 \\
(1.51)\end{array}$ & $\begin{array}{c}0.010 * * \\
(3.27)\end{array}$ & $\begin{array}{c}0.010 * * \\
(3.14)\end{array}$ & $\begin{array}{l}0.008 \\
(1.41) \\
\end{array}$ & $\begin{array}{l}0.004 \\
(1.05) \\
\end{array}$ & $\begin{array}{c}0.005 * * \\
(4.58)\end{array}$ \\
\hline $\begin{array}{l}\text { Growth rate of GDP (- } \\
\text { 1) }\end{array}$ & $\begin{array}{l}-0.268 \\
(-0.35) \\
\end{array}$ & $\begin{array}{l}-0.575 \\
(-1.56) \\
\end{array}$ & $\begin{array}{l}-0.625 \\
(-1.77) \\
\end{array}$ & $\begin{array}{l}-0.072 \\
(-0.17) \\
\end{array}$ & $\begin{array}{l}-0.479 \\
(-1.01) \\
\end{array}$ & $\begin{array}{l}0.130 \\
(0.23)\end{array}$ \\
\hline $\begin{array}{l}\text { Growth rate of GDP (- } \\
\text { 2) }\end{array}$ & $\begin{array}{l}-0.483 * \\
(-1.67)\end{array}$ & $\begin{array}{c}-0.985 * * \\
(-2.78)\end{array}$ & $\begin{array}{c}-0.958 * * \\
(-3.71)\end{array}$ & $\begin{array}{c}-0.925 * * \\
(-3.51)\end{array}$ & $\begin{array}{l}0.148 \\
(0.75) \\
\end{array}$ & $\begin{array}{l}-0.013 \\
(-0.03) \\
\end{array}$ \\
\hline Public consumption & $\begin{array}{l}0.400 \\
(0.49)\end{array}$ & & & & & \\
\hline Trade (\% of GDP) & & $\begin{array}{c}0.0003 \\
(0.16) \\
\end{array}$ & & & & \\
\hline $\operatorname{GDP}(-1)$ & & & $\begin{array}{l}0.0007 \\
(0.07) \\
\end{array}$ & & & \\
\hline $\begin{array}{l}\text { Tertiary school } \\
\text { enrollment rate }\end{array}$ & & & & $\begin{array}{l}-0.0001 \\
(-0.11) \\
\end{array}$ & & \\
\hline Constant & $\begin{array}{c}-0.337 * * \\
(-2.59)\end{array}$ & $\begin{array}{c}-0.365 * * \\
(-3.27)\end{array}$ & $\begin{array}{l}-0.394 * \\
(-1.92)\end{array}$ & $\begin{array}{l}-0.210^{*} \\
(-1.77)\end{array}$ & $\begin{array}{l}-0.017 \\
(-0.12)\end{array}$ & $\begin{array}{l}-0.037 \\
(-0.41)\end{array}$ \\
\hline Country Fixed Effects & Yes & Yes & Yes & Yes & Yes & Yes \\
\hline Time Effects & Yes & Yes & Yes & Yes & Yes & Yes \\
\hline Hansen test $(p \text {-value })^{\dagger \dagger}$ & $\begin{array}{c}8.91 \\
(0.63)\end{array}$ & $\begin{array}{l}4.59 \\
(0.94)\end{array}$ & $\begin{array}{l}4.60 \\
(0.94)\end{array}$ & $\begin{array}{c}6.43 \\
(0.84)\end{array}$ & $\begin{array}{l}4.15 \\
(0.76)\end{array}$ & $\begin{array}{l}7.26 \\
(0.84)\end{array}$ \\
\hline $\begin{array}{l}\text { Autocor. Test (p- } \\
\text { value) }\end{array}$ & $\begin{array}{c}0.53 \\
(0.59) \\
\end{array}$ & $\begin{array}{c}1.03 \\
(0.30) \\
\end{array}$ & $\begin{array}{c}1.10 \\
(0.27) \\
\end{array}$ & $\begin{array}{l}1.15 \\
(0.25) \\
\end{array}$ & $\begin{array}{l}-1.30 \\
(0.19) \\
\end{array}$ & $\begin{array}{l}-0.16 \\
(0.87) \\
\end{array}$ \\
\hline Observations & 280 & 280 & 280 & 254 & 280 & 280 \\
\hline
\end{tabular}

$\dagger$ The z-statistics are reported in parentheses. †† The null hypothesis is that the instruments used in the regression are valid. $\dagger \dagger \uparrow$ The null hypothesis is that the errors in the first-differenced regression exhibit no second order serial correlation. ** Significant at the 5\% level. * Significant at the $10 \%$ level. 
Table 6 System GMM Econometric Estimates (Various efficiency sub-indices)

\begin{tabular}{|c|c|c|c|c|}
\hline \multicolumn{5}{|c|}{ Dependent variable: Growth rate of GDP } \\
\hline & $\begin{array}{c}\text { Administration } \\
\text { index }\end{array}$ & $\begin{array}{l}\text { Stabilization } \\
\text { index }\end{array}$ & $\begin{array}{l}\text { Education } \\
\text { index }\end{array}$ & $\begin{array}{l}\text { Infrastructure } \\
\text { index }\end{array}$ \\
\hline Public investment & $\begin{array}{l}0.007 \\
(0.52)\end{array}$ & $\begin{array}{c}0.018 * * \\
(2.01)\end{array}$ & $\begin{array}{l}0.009 \\
(1.29)\end{array}$ & $\begin{array}{l}0.011 \\
(0.90)\end{array}$ \\
\hline Efficiency & $\begin{array}{c}-0.0003 \\
(-0.07) \\
\end{array}$ & $\begin{array}{l}0.026 \\
(0.86) \\
\end{array}$ & $\begin{array}{l}-0.022 \\
(-0.35) \\
\end{array}$ & $\begin{array}{l}0.015 \\
(0.85) \\
\end{array}$ \\
\hline $\begin{array}{l}\text { Public } \\
\text { investment*Efficiency }\end{array}$ & $\begin{array}{l}0.004 \\
(0.29) \\
\end{array}$ & $\begin{array}{c}0.027 * * \\
(2.66) \\
\end{array}$ & $\begin{array}{c}0.028 * * \\
(1.97) \\
\end{array}$ & $\begin{array}{c}0.013 * \\
(1.87) \\
\end{array}$ \\
\hline Private investment & $\begin{array}{l}0.009^{*} \\
(1.78)\end{array}$ & $\begin{array}{l}0.004 \\
(0.96)\end{array}$ & $\begin{array}{c}0.013 * * \\
(2.35)\end{array}$ & $\begin{array}{c}0.009 * * \\
(2.32)\end{array}$ \\
\hline Growth rate of GDP $(-1)$ & $\begin{array}{l}-0.075 \\
(-0.27)\end{array}$ & $\begin{array}{l}-0.206 \\
(-0.41)\end{array}$ & $\begin{array}{l}-0.280 \\
(-1.03)\end{array}$ & $\begin{array}{l}-0.543 \\
(-1.06)\end{array}$ \\
\hline Growth rate of GDP $(-2)$ & $\begin{array}{l}-0.323 \\
(-1.08)\end{array}$ & $\begin{array}{l}-0.510 \\
(-1.16)\end{array}$ & $\begin{array}{l}-0.628 \\
(-1.40)\end{array}$ & $\begin{array}{l}-0.243 \\
(-0.83)\end{array}$ \\
\hline Constant & $\begin{array}{c}-0.162 * * \\
(-2.34)\end{array}$ & $\begin{array}{l}-0.146^{*} \\
(-1.66)\end{array}$ & $\begin{array}{l}-0.208^{*} \\
(-1.94)\end{array}$ & $\begin{array}{c}-0.214 * * \\
(-2.48)\end{array}$ \\
\hline Country Fixed Effects & Yes & Yes & Yes & Yes \\
\hline Time Effects & Yes & Yes & Yes & Yes \\
\hline Hansen test (p-value) $)^{\dagger \dagger}$ & $\begin{array}{l}13.11 \\
(0.36) \\
\end{array}$ & $\begin{array}{l}14.16 \\
(0.36) \\
\end{array}$ & $\begin{array}{c}9.99 \\
(0.61) \\
\end{array}$ & $\begin{array}{l}17.61 \\
(0.61) \\
\end{array}$ \\
\hline Autocor. Test (p-value) & $\begin{array}{c}0.71 \\
(0.47) \\
\end{array}$ & $\begin{array}{c}0.87 \\
(0.38) \\
\end{array}$ & $\begin{array}{c}0.88 \\
(0.38) \\
\end{array}$ & $\begin{array}{l}-0.44 \\
(0.66) \\
\end{array}$ \\
\hline Observations & 280 & 308 & 280 & 252 \\
\hline
\end{tabular}

$\dagger$ The z-statistics are reported in parentheses. $\dagger \dagger$ The null hypothesis is that the instruments Used in the regression are valid. $\uparrow \dagger \dagger$ The null hypothesis is that the errors in the first-differenced regression exhibit no second order serial correlation. ** Significant at the 5\% level. * Significant at the $10 \%$ level. 
Table7 Alternative public sector efficiency indicators

\begin{tabular}{|l|c|c|c|c|c|c|}
\hline & $\begin{array}{c}\text { Administration } \\
\text { index (2013) }\end{array}$ & $\begin{array}{c}\text { Stabilization } \\
\text { index } \\
(2014)\end{array}$ & $\begin{array}{c}\text { Education } \\
\text { index } \\
(2013)\end{array}$ & $\begin{array}{c}\text { Infrastructure } \\
\text { index (2014) }\end{array}$ & $\begin{array}{c}\text { Total Index } \\
\text { (equal } \\
\text { weights, } \\
\text { 2013) }\end{array}$ & $\begin{array}{c}\text { Total Index } \\
\text { (different } \\
\text { weights, } \\
\text { 2013) }\end{array}$ \\
\hline Croatia & 0.60 & 0.52 & 0.73 & 0.33 & 0.55 & 0.48 \\
\hline Romania & 0.60 & 0.92 & 0.58 & 0.19 & 0.57 & 0.44 \\
\hline Slovakia & 0.73 & 0.59 & 0.64 & 0.28 & 0.57 & 0.47 \\
\hline Greece & 0.62 & 0.36 & 0.99 & 0.40 & 0.60 & 0.53 \\
\hline Cyprus & 0.83 & 0.71 & 0.51 & 0.34 & 0.61 & 0.52 \\
\hline Bulgaria & 0.63 & 0.77 & 0.83 & 0.26 & 0.62 & 0.50 \\
\hline Spain & 0.79 & 0.25 & 0.99 & 0.50 & 0.64 & 0.59 \\
\hline Italy & 0.58 & 0.56 & 0.87 & 0.57 & 0.66 & 0.63 \\
\hline Poland & 0.80 & 0.67 & 0.92 & 0.27 & 0.67 & 0.54 \\
\hline Malta & 0.92 & 0.90 & 0.49 & 0.39 & 0.68 & 0.58 \\
\hline Ireland & 0.86 & 0.58 & 0.86 & 0.43 & 0.68 & 0.60 \\
\hline Czech Republic & 0.85 & 0.90 & 0.71 & 0.34 & 0.70 & 0.58 \\
\hline Latvia & 0.85 & 0.74 & 0.95 & 0.29 & 0.71 & 0.57 \\
\hline Lithuania & 0.86 & 0.75 & 0.95 & 0.29 & 0.71 & 0.57 \\
\hline Hungary & 0.91 & 0.88 & 0.78 & 0.33 & 0.72 & 0.59 \\
\hline Portugal & 0.89 & 0.69 & 0.87 & 0.43 & 0.72 & 0.62 \\
\hline Luxembourg & 0.90 & 0.89 & 0.20 & 0.99 & 0.75 & 0.83 \\
\hline Slovenia & 0.80 & 0.81 & 0.98 & 0.40 & 0.75 & 0.64 \\
\hline Austria & 0.87 & 0.83 & 0.89 & 0.52 & 0.78 & 0.70 \\
\hline Estonia & 0.95 & 0.86 & 0.99 & 0.43 & 0.81 & 0.68 \\
\hline Belgium & 0.93 & 0.79 & 0.99 & 0.53 & 0.82 & 0.72 \\
\hline Finland & 0.96 & 0.77 & 0.99 & 0.62 & 0.84 & 0.77 \\
\hline Denmark & 0.96 & 0.90 & 0.99 & 0.59 & 0.86 & 0.77 \\
\hline France & 0.93 & 0.72 & 0.86 & 0.99 & 0.88 & 0.92 \\
\hline Germany & 0.93 & 0.81 & 0.84 & 0.99 & 0.90 & 0.93 \\
\hline United Kingdom & 0.94 & 0.87 & 0.93 & 0.99 & 0.93 & 0.95 \\
\hline Sweden & 0.96 & 0.86 & 0.99 & 0.98 & 0.95 & 0.96 \\
\hline Netherlands & 0.95 & 0.91 & 0.95 & 0.99 & 0.95 & 0.96 \\
\hline
\end{tabular}

* Countries are ranked in ascending order of the total public sector efficiency index (equal weights).

$* *$ Scores for the administration index end in 2013, for the stabilization index in 2014, for the education index in 2013, for the infrastructure index in 2014 and for the total indexes in 2013. 
Table 8 System GMM Econometric Estimates

(Alternative efficiency index)

\begin{tabular}{|c|c|c|}
\hline \multicolumn{3}{|c|}{ Dependent variable: Growth rate of GDP } \\
\hline & $\begin{array}{c}\text { Total Index } \\
\text { (equal weights) }\end{array}$ & $\begin{array}{c}\text { Total Index } \\
\text { (different } \\
\text { weights) }\end{array}$ \\
\hline Public investment & $\begin{array}{l}0.007 \\
(0.97)\end{array}$ & $\begin{array}{l}0.003 \\
(0.23) \\
\end{array}$ \\
\hline Efficiency & $\begin{array}{l}0.124 \\
(1.25)\end{array}$ & $\begin{array}{l}0.086 \\
(1.36) \\
\end{array}$ \\
\hline Public investment*Efficiency & $\begin{array}{c}0.016 * * \\
(2.17) \\
\end{array}$ & $\begin{array}{l}0.019 \\
(1.36) \\
\end{array}$ \\
\hline Private investment & $\begin{array}{l}0.001 \\
(0.30)\end{array}$ & $\begin{array}{l}0.005 \\
(1.36)\end{array}$ \\
\hline Growth rate of GDP $(-1)$ & $\begin{array}{l}-0.106 \\
(-0.29) \\
\end{array}$ & $\begin{array}{l}-0.150 \\
(-0.46) \\
\end{array}$ \\
\hline Growth rate of GDP $(-2)$ & $\begin{array}{l}-0.530 \\
(-1.22)\end{array}$ & $\begin{array}{l}-0.193 \\
(-0.41)\end{array}$ \\
\hline Constant & $\begin{array}{l}-0.125 \\
(-0.99) \\
\end{array}$ & $\begin{array}{l}-0.151 \\
(-2.05) \\
\end{array}$ \\
\hline Country Fixed Effects & Yes & Yes \\
\hline Time Effects & Yes & Yes \\
\hline Hansen test (p-value) ${ }^{\dagger \dagger}$ & $\begin{array}{c}8.21 \\
(0.77) \\
\end{array}$ & $\begin{array}{c}9.43 \\
(0.66) \\
\end{array}$ \\
\hline Autocor. Test (p-value) & $\begin{array}{c}0.95 \\
(0.34)\end{array}$ & $\begin{array}{c}0.23 \\
(0.82)\end{array}$ \\
\hline Observations & 280 & 280 \\
\hline
\end{tabular}

$\dagger$ The $\mathrm{z}$-statistics are reported in parentheses. $\dagger \dagger$ The null hypothesis is that the instruments used in the regression are valid. $\dagger \dagger \dagger$ The null hypothesis is that the errors in the first-differenced regression exhibit no second order serial correlation. ** Significant at the 5\% level. * Significant at the $10 \%$ level. 
Figure 2 Growth impact of public investment at various levels of government efficiency

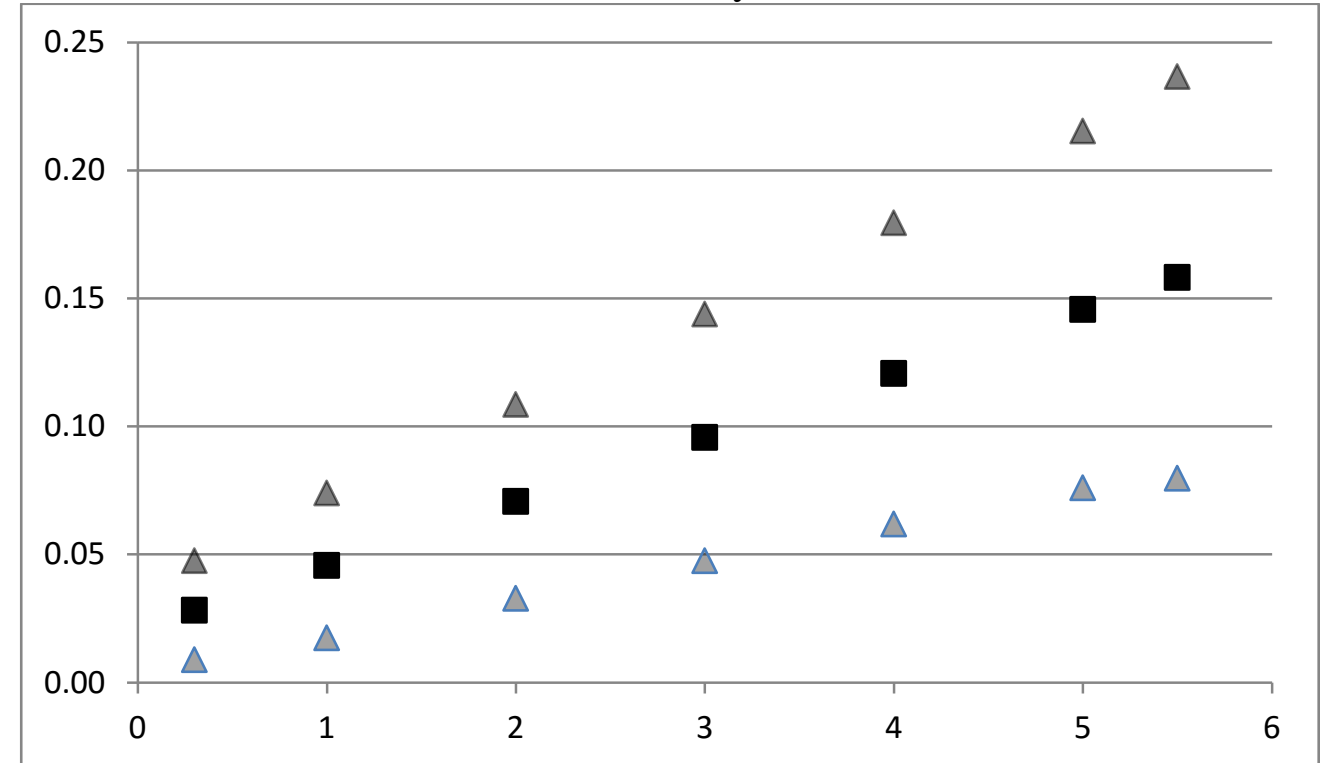

Note: Squares are coefficients and triangles are two standard error confidence intervals. 